\title{
Makna Hidup pada Wanita Dewasa yang Terlambat Menikah
}

\author{
The Meaning of Life for Unmarried Women
}

\author{
Maqhfirah DR \\ Universitas Medan Area, Sumatera Utara-Indonesia
}

Diterima; Mei 2018; Disetujui: Oktober 2018; Dipublish: Desember 2018 Corresponding author: E-mail: Maqhfirahdr@yahoo.com

\begin{abstract}
Abstrak
Penelitian ini merupakan penelitian kualitatif mengenai makna hidup pada wanita dewasa yang terlambat menikah. Ada empat hal yang diteliti yaitu faktor penyebab, dampak psikologis yang dialami, strategi coping yang digunakan, dan makna hidup yang dimiliki wanita dewasa yang terlambat menikah. Teknik pengumpulan data menggunakan wawancara dan observasi. Responden berjumlah dua orang wanita berusia 40 tahun ke atas dan belum menikah. Penelitian ini didukung teori logoterapi oleh Victor Frankl. Makna hidup yang dirasakan responden merupakan suatu bentuk penghayatan hidup yang berasal dari penderitaan yang dirasakan responden dengan status terlambat menikah. Hasil penelitian menunjukkan bahwa faktor yang menyebabkan kedua responden terlambat menikah adalah faktor punya 'apa-apa' dulu, faktor berbakti kepada orang tua, dan faktor selera tinggi, namun pada responden I faktor study oriented dan faktor menikah itu susah juga menjadi faktor penyebabnya. Kedua responden menikmati status mereka yang terlambat menikah berupa memperoleh kebebasan, kemandirian dalam pengambilan keputusan, namun mereka memperoleh dampak negatif berupa merasa kesulitan dalam memenuhi kebutuhan seksual, merasa kesulitan ketika dalam keadaan sakit, dan juga adanya norma yang berasal dari agama dan budaya setempat yang menganggap wanita yang terlambat menikah kurang beruntung dan belum lengkap sebagai wanita.
\end{abstract}

Kata Kunci: Makna Hidup, Wanita Terlambat Menikah

\begin{abstract}
This research was a qualitative research regarding the meaning of life for unmarried woman. There are four components that were explored, the causes and psychological effect they experienced, coping strategy that used and the meaning of life that was owned by those women. The technique for collecting data using interview and observation sheet. The respondents was above 40 years old and unmarried. This research was supported by logotherapy theory of Victor Frankl. The meaning of life for these respondents was a kind of full life experiences that came from their suffering of being not married yet. The result of the this research showed thet the factors affecting both respondents had not get married because they want to be established before get married, dedication to their parents, and having a high standard factors. But for respondent I, study oriented factor and difficulty of married was also of factors. Both respondents enjoyed their unmarried status became they have freedom and autonomy in determining this own decision. But they have negative effect such as difficulty to fulfill their sexual need and difficulty when they got sick wothout any help from other people and feeling uncomfortable because of the norms from their religion and culture which considered unmarried woman as unlucky and incomplete as a woman.
\end{abstract}

Keywords: The Meaning of Life, Unmarried Woman

How to Cite: Maqhfirah DR, (2018), Makna Hidup Pada Wanita Dewasa Yang Terlambat Menikah, Jurnal Diversita, 4 (2): 109-118 


\section{PENDAHULUAN}

Menurut teori perkembangan, masa usia menikah adalah saat usia dewasa awal yaitu 20-40 tahun (Papalia, Old \& Feldman, 2008) atau usia 21-40 tahun (Hurlock, 1980). Dengan kata lain, masa dewasa awal merupakan masa dimana seorang individu mulai mengemban tugas untuk menikah dan membina keluarga. Hal ini sejalan dengan pendapat Havigurst (dalam Hurlock, 1980) yang menyatakan bahwa tugas perkembangan yang menjadi karakteristik dewasa awal adalah mulai memilih pasangan hidup dan mulai bekerja.

Kenyataan yang pasti bahwa dalam suatu budaya yang di dalamnya perkawinan merupakan pola yang normal bagi kehidupan orang dewasa, sebagian besar orang dewasa ingin menikah dan mengalami tekanan dari orang tua dan teman-temannya agar segera menikah. Selama duapuluhan tujuan dari sebagian besar wanita yang belum menikah dalah perkawinan. Apabila ia belum juga menikah pada waktu ia telah mencapai usia tigapuluhan atau persis pada hari ulang tahunnya yang ketigapuluh, maka ia cenderung untuk menukar tujuan dan nilai hidupnya ke arah nilai dan tujuan serta gaya hidup yang berorientsi pada pekerjaan, kesuksesan dalam karir, dan kesenangan pribadi (Hurlock, 1980).

Menurut Al'Uwaid (2005), sebenarnya banyak sebab yang melatarbelakangi fenomena wanita terlambat menikah. Beberapa diantaranya adalah kemungkinan berperannya sikap orang tua yang menolak kepada setiap laki-laki yang datang melamar putrinya. Selain itu, kemungkinan juga dari pihak wanitanya sendiri yang tidak menyukai laki-laki yang melamarnya. Tradisi yang berlaku dalam keluarga dan masyarakat juga bisa menjadi penghalang beberapa wanita terlambat menikah. Seperti halnya perbedaan suku, keinginan melanjutkan pendidikan terlebih dahulu, sulitnya menikah dengan orang di luar negaranya, dan beberapa masalah lainnya bisa menjadi salah satu faktor para wanita terlambat menikah.

Hurlock (1980) mengatakan usia tia puluh disebut usia krisis (critical age) bagi wanita yang belum menikah. Seperti yang ditunjukkan oleh Campbell: " bagi wanita, usia tiga puluh merupakan pilihan yang mempunyai persimpangan". Karena hidup wanita sering diwarnai dengan stres ketika dia mencapai ulang tahunnya yang ketigapuluh tetapi belum juga menikah. Stres ini biasa mencapai puncaknya pada usia tiga puluh, kemudian secara bertahap berkurang karena dia mulai menyesuaikan diri dengan gaya hidup yang lain dan baru. Bagi kebanyakan wanita, keinginan untuk menikah dan berkeluarga berkurang setelah usia tiga puluh karena mereka sadar bawa nampaknya mereka tidak dapat mencapai tujuannya.

Pada umumnya wanita cukup realistis untuk mengetahui bahwa setelah mereka lewat empat puluh, kesempatan mereka untuk menikah semakin kecil. Sadar akan kecilnya kemungkinan menikah, maka wanita yang belum menikah pada usia ini berusaha menyesuiakan pola hidupnya setepat mungkin dan sering memusatkan perhatiannya pada pekerjaan. 
Frankl (dalam Bastaman, 2007) menyatakan bahwa makna hidup adalah hal-hal yang dianggap sangat penting dan berharga serta memberikan nilai khusus bagi seseorang, sehingga layak dijadikan tujuan dalam kehidupan (the purpose in life). Makna hidup ternyata ada dalam hidup itu sendiri, dan dapat ditemukan dalam setiap keadaan yang menyenangkan dan tidak menyenangkan, keadaan bahagia, dan penderitaan. Ungkapan seperti "Makna dalam Derita" (Meaning in Suffering) atau "Hikmah dalam Musibah" (Blessing in Disguise) menunjukkan bahwa dalam penderitaan sekalipun makna hidup dapat tetap ditemukan. Pengertian mengenai makna hidup menunjukkan bahwa dalam makna hidup terkandung juga tujuan hidup, yakni hal-hal yang perlu dicapai dan dipenuhi.

Dalam kehidupan ini terdapat tiga bidang kegiatan yang secara potensial mengandung nilai-nilai yang memungkinkan seseorang menemukan makna hidup didalamnya apabila nilainilai itu diterapkan dan dipenuhi. Ketiga nilai (values) yang dimaksud adalah nilainilai kreatif (creative values), nilai-nilai penghayatan (experiental values), dan nilai-nilai bersikap (attitudinal values). Selain ketiga nilai tersebut, ada nilai lain yang dapat menjadikan hidup ini bermakna yaitu nilai pengharapan (hopeful values). Pengharapan mengandung makna hidup karena adanya keyakinan akan terjadinya perubahan yang lebih baik, ketabahan menghadapi keadaan buruk saat ini dan sikap optimis menyongsong masa depan.

Bagaimana perasaan wanita yang terlambat menikah jelas berbeda-beda, sesuai dengan latar belakang sosialnya. Mereka yang tinggal di pedesaan, kota kecil, atau pinggiran kota tetapi tidak/belum menikah aka menghadapi tantangan yang lebih berat daripada mereka yang tinggal di kota. Meskipun demikian, ada sebagian besar dari mereka merasa dapat hidup tenang dan sebagian masyarakat lingkungan mereka juga sudah bisa menerima hal tersebut sebagai sesuatu yang wajar.

\section{METODE PENELITIAN}

Pendekatan kualitatif mencoba menterjemahkan pandangan dasar interpretatif dan fenomenologis untuk memahami kehidupan sosial. Pendekatan ini menghasilkan dan mengolah data yang bersifat deskriptif seperti transkip wawancara, catatan lapanagan, foto, rekaman video dan sebagainya (Poerwandari, 2007). Merujuk pada masalah yang hendak dijawab maka penelitian ini menggunakan pendekatan kualitatif yang dipandang dapat mengetahui lebih jelas bagaimana makna hidup pada wanita dewasa yang terlambat menikah dengan cara deskriptif dalam bentuk kata-kata, bahasa, perilaku pada konteks khusus yang alamiah dan memanfaatkan berbagai metode pengambilan data. Pada penelitian ini metode pengambilan data menggunakan metode wawancara dan observasi. Wawancara dilengkapi dengan pedoman wawancara dengan mencantumkan isi-isu yang harus diliput tanpa menentukan urutan pertanyaan. Sementara observasi dilakukan observasi partisipan dengan mengamati langsung aktivitas responden. Observasi menggunakan catatan lapangan dan juga 
dilakukan pengamatan terhadap situasi dan kondisi pada saat wawancara dilakukan, intonasi suara dan mimik responden dan interaksi responden dengan lingkungannya.

Responden dalam penelitian ini berjumlah 2 orang yang diambil dengan cara teknik purposive sampling dengan kriteria: wanita berusia 40 tahun ke atas, dan belum menikah. Penelitian dilakukan di Takengon, NAD selama 3 bulan. Penelitian ini menggunakan triangulasi data, triangulasi peneliti, dan triangulasi metode. Penggunaan ketiga triangulasi ini dimaksudkan agar hasil penelitian dapat dipertanggungjawabkan.

\section{HASIL DAN PEMBAHASAN}

\section{Hasil Analisis Intrapersonal Responden I}

Pada responden I, faktor terlambat menikah disebabkan oleh faktor berbakti kepada orang tua berupa kepatuhannya untuk segera menyelesaikan kuliah sebelum menikah, study oriented berupa ketekunannya menyelesaikan kuliah, punya 'apa-apa' dulu berupa menomorsatukan pekerjaan dan ingin mapan sebelum menikah, menikah itu susah berupa rasa takut setelah mendengar cerita mengenai maalah yang dihadapi dalam berumah tangga, dan selera tinggi yang ditandai dengan keinginan agar calon suaminya laki-laki lajang, usianya lebih tua darinya dan punya pekerjaan.

Dampak psikologis yang dirasakan berupa memperoleh nilai kebebasan dibandingkan wanita yang sudah berkeluarga, kemandirian dalam pengambilan keputusan terutama yang menyangkut pekerjaan namun terkadang ia butuh orang lain untuk berdiskusi, merasa kesulitan untuk memenuhi kebutuhan seksual yang datang setiap bulannya, butuh orang lain ketika sakit dan akan matah jika disinggung pernikahan oleh keluarga dekat. Ia merasa sedih dan resah karena belum juga menikah.

Strategi coping yang digunakan Responden I adalah jenis problemfocused coping berupa konfrontasi dengan cara marah dan membanting pintu, mencari dukungan sosial dengan cara bercerita kepada sahabat, dan jenis emotion-focused coping berupa membuat jarak dengan cara pergi dari rumah untuk sementara waktu, kontrol diri dengan cara diam, penilaian kembali secara positif dengan cara pasrah dan menerima jika nantinya ia harus menikah dengan seorang duda dan lari/penghindaran dengan cara merokok dan mencari kesibukan.

Responden I memiliki aspek-aspek makna hidup dalam kehidupannya yaitu maksud dan tujuan hidup berupa membahagiakan ibunya dan menikah, kepuasan hidup karena ia sudah dapat mewujudkan keinginan orangtuanya untuk menyelesaikan kuliah dan mempunyai penghasilan dari pekerjaannya sebagai PNS, kebebasan yang dapat ia gunakann didukung kepercayaan dari keluarga dan sikapnya terhadap kematian untuk memiliki anak agar tidak mengalami kejadian seperti temannya. Ia memiliki sumber-sumber makna hidup dalam hidupnya yaitu nilainilai kreatif berupa pekerjaan dan berkarya sebagai penyemangat hidup, nilai-nilai penghayatan berupa keyakinan bahwa keadaannya saat ini adalah hal 
yang terbaik dari Allah, nilai-nilai bersikap berupa sikap menerima keadaannya saat ini dan nilai-nilai pengharapan berupa keinginan untuk hidup bahagia dengan berkeluarga. Ia memiliki karakteristik makna hidup dalam hidupnya yaitu bersifat unik, pribadi, dan temporer berupa pekerjaannya sebagai PNS, bersifat spesifik dan nyata berupa pengalaman ketika orangtuanya disumpahi orang dan cerita dari kawan-kawannya yang sudah berkeluarga serta kegiatan yang memberi pedoman dan arah berupa ibadah dan pekerjaan. Penghayatan hidup bermakna ditandai dengan pemaknaan positif terhadap dirinya dan mensyukuri apapun yang ia miliki saat ini.

\section{Hasil Analisis Intrapersonal Responden II}

Faktor yang menyebabkan Responden II terlambat menikah adalah selera tinggi dengan menetapkan kriteria laki-laki yang tidak hanya menikahinya tetapi juga keluarganya, melindungi, tidak mengekang, good looking, pintar dan punya penghasilan, dan berbakti kepada orang tua yang ditandai dengan pilihannya untuk tidak ingin jauh dari keluarga yang sewaktu itu ayahnya sudah mulai sakit-sakitan, serta punya 'apa-apa' dulu dengan keinginan hidup mapan sebelum menikah.

Responden II memperoleh nilai kebebasan karena belum berkeluarga, kemandiria dalam pengambilan keputusan namun tidak untuk masalah keluarga ia butuh orang lain, merasa kesulitan untuk memenuhi kebutuhan seksual yang datang setiap bulannya, kesulitan ketika dalam keadaan sakit apalagi setelah kedua orangtuanya tiada dan menanggapi secara biasa perkataan dan pertanyaan orang-orang namun terkadang ia sedih karena ia merasa hidupnya belum sempurna dari sudut agama dan karena pernikahan adalah keinginan almarhumah ibunya.

Bentuk strategi coping yang dimiliki responden II adalah bentuk problemfocused coping berupa konfrontasi dengan cara marah, mencari dukungan sosial dengan cara berbagi cerita dengan orang yang dapat dipercaya, merencanakan pemecahan masalah dengan cara melakukan beberapa langkah penyelesaian masalah dan bentuk emotion-focused coping berupa penilaian kembali secara positif dengan cara berserah kepada Allah dan lari/penghindaran dengan cara menangis dan mencari kesibukan.

Ia memiliki aspek-aspek makna hidup dalam kehidupannya diantaranya maksud dan tujua hidup berupa keinginan untuk menjadi lebih baik setiap harinya dan merawat rumah peninggalan orangtuanya, kepuasan hidup ketika memiliki waktu yang lama umtuk merawat ibunya yang sakit dan pekerjaannya sebagai PNS, kebebasan yang dipergunakan secara wajar dengan pertimbangan ke depan dan rasa takut terhadap kematian karena belum berkeluarga namun ketakutan itu dapat reda ketika ia sadar bahwa ia punya keluarga dan para ponakan yang menyayanginya. Ia memiliki sumbersumber makna hidup dalam kehidupannya berupa nilai-nilai kreatif yaitu semangat hidup dengan bekerja dan berkarya, nilai-nilai penghayatan 
yaitu dengan tetap bersyukur, nilai-nilai bersikap yaitu menyikapi hidup secara positif dan berusaha untuk menjalani hidup semampunya dan nilai-nilai pengharapan yaitu keinginan menikah dan keinginan untuk menunaikan ibadah haji seperti yang pernah ia cita-citakan ketika dulu ibunya masih ada. Ia memiliki karakteristik makna hidup dalam kehidupannya antara lain bersifat unik, pribadi dan temporer berupa kesehatan dan keluarga, bersifat spesifik dan nyata berupa pengalaman setelah kedua orangtuanya meninggal yang membuatnya kuat dan mandiri seperti saat ini serta kegiatan yang memberinya pedoman dan arah berupa ibadah dan pekerjaan. Ia memiliki penghayatan hidup bermakna dengan memaknai hidup secara positif dan berusaha untuk menjalani hidup dengan baik.

\section{Hasil Analisis Interpersonal}

Faktor yang menyebabkan kedua responden terlambat menikah adalah punya 'apa-apa' dulu yaitu keinginan mapan sebelum menikah, berbakti kepada orang tua yaitu kepatuhan responden I untuk menyelesaikan kuliah sebelum menikah dan responden II yang tidak ingin jauh dari keluarga semenjak ayahnya mulai sakit-sakitan, dan selera tinggi yaitu adanya kriteria yang kedua responden tetapkan untuk calon suami mereka, namun pada responden I masih ada faktor penyebab yang lain diantaranya study oriented yaitu ketekunannya menyelesaikan kuliah dan menikah itu susah berupa rasa takut menghadapi permasalahan ketika menikah.
Dampak psikologis yang dirasakan oleh kedua responden yakni merasa memperoleh kebebasan dengan kehidupan mereka yang belum menikah, mandiri dalam pengambilan keputusan namun ada kalanya mereka butuh orang lain untuk berdiskusi, keduanya merasa kesulitan dalam memenuhi kebutuhan seksual yang datang setiap bulannya, kesulitan ketika dalam keadaan sakit, responden I menanggapi norma yang berasal dari agama dengan sedih dan rasa resah sedangkan responden II menanggapinya dengan sedih karena ia merasa hidupnya belum sempurna dari sudut agama dan karena pernilahan adalah keinginan almarhumah ibunya.

Strategi coping yang dimiliki kedua responden adalah bentuk problemfocused coping yaitu konfrontasi dengan cara marah dan mencari dukungan sosial dengan cara berbagi masalah dengan orang yang dipercaya, namun responden II menambahkan jenis merencanakan pemecahan masalah menjadi salah satunya dengan cara melakukan beberapa langkah penyelesaian masalah, dan bentuk emotion-focused coping yaitu penilaian kembali secara positif dengan cara menerima dan berserah diri kepada Allah, lari/penghindaran dengan cara mencari kesibukan. Responden I menambahkan jenis membuat jarak dengan cara pergi dari rumah dan kontrol diri dengan cara diam.

Kedua responden telah memenuhi aspek-aspek makna hidup dalam kehidupan mereka diantaranya maksud dan tujuan hidup, kepuasan hidup, kebebasan, dan sikap terhadap kematian. Keduanya memiliki sumber-sumber makna hidup dalam kehidupan mereka 
yaitu berupa nilai-nilai kreatif, nilai-nilai penghayatan, nilai-nilai bersikap, dan nilai-nilai pengharapan. Mereka memiliki karakteristik makna hidup yaitu bersifat unik, pribadi dan temporer, bersifat spesifik dan nyata serta memberikan pedoman dan arah dalam hidup mereka. Kedua responden memiliki penghayatan hidup bermakna ditandai dengan pemaknaan hidup secara positif terhadap diri dan kehidupan mereka.

Faktor-faktor yang menyebabkan kedua responden terlambat menikah diantaranya faktor punya 'apa-apa' dulu, faktor berbakti kepada orang tua, dan faktor selera tinggi serta ditambah dengan faktor study oriented pada respinden I. Faktor-faktor tersebut sesuai dengan yang diungkapkan oleh Hermawan (dalam Al'Uwaid, 2005). Keduanya memperoleh nilai kebebasan dengan kehidupan mereka yang belum menikah, namun kemandirian mereka dalam mengambil suatu keputusan tetap membutuhkan orang lain sebagai teman berbagi dan berdiskusi. Keduanya juga mengalami kesulitan dalam memenuhi kebutuhan seksual dan merasa kesulitan ketika beda dalam keadaan sakit. Perasaan sedih, takut dan khawatir walaupun mereka punya keluarga dan orang-orang terdekat lainnya yang tentunya akan mengurus mereka jika ajal datang menjemput. Norma yang berasal dari agama dan budaya setempat membuat keduanya merasa hidup mereka belum lengkap karena belum menikah. Adat istiadat yang masih dipegang kuat oleh masyarakat tempat mereka tinggal sering memandang negatif dan menyudutkan orang-orang dengan status terlambat menikah. Segi untung rugi menjalani kehidupan sendiri sebagai dampak psikologis yang harus diterima oleh kedua responden tersebut sesuai dengan apa yang dikatakan Santrock (dalam Dariyo, 2008).

Seperti yang diungkapkan oleh Folkman et al (dalam Smeth, 1994), bahwa ada variasi dari dua macam strategi coping bentuk problem-focused coping yakni konfrontasi, mencari dukungan sosial, dan merencanakan pemecahan masalah, dan bentuk emotion-focused coping yakni kontrol diri, membuat jarak, penilaian kembali secara positif, menerima tanggung jawab dan lari/penghindaran. Responden I menggunakan coping jenis konfrontasi, membuat jarak, kontrol diri, mencari dukungan sosial, lari/penghindaran dan penilaian kembali secara positif sebagai usaha untuk menyelesaikan masalah yang ia hadapi. Ia aka marah dan pergi dari rumah untuk sesaat jika disinggung masalah pernikahan. Terkadang ia memilih diam dan tidak peduli mengenai apapun yang dikatakan orang terhadapnya. Ia berusaha menyimpan masalahnya dan jika saatnya tepat ia akan mencurahkan segala permaalahan yang ia hadapi dengan bercerita kepada sahabat yang sekaligus kakak angkatnya. Ia juga mencari kesibukan yang dapat mengalihkannya dari permasalahan. Ia pasrah dan menerima siapapun yang menjadi pendamping hidupnya. Tidak jauh berbeda dari responden I, responden II memilih konfrontasi, lari/penghindaran, mencari dukungan sosial, merencanakan pemecahan masalah dan penilaian kembali secara positif sebagai strategi coping dalam menghadapi masalahnya. Ia akan marah 
dan menangis, mencari kesibukan, bercerita kepada orang yang dapat dipercaya, melakukan beberapa langkah dan berserah diri kepada Allah guna menyelesaikan masalahnya.

Menurut Frankl (dalam Bastaman, 2007) makna hidup adalah hal-hal yang dianggap sangat penting dan berharga serta memberikan nilai khusus bagi seseorang, sehingga layak dijadikan tujuan dalam kehidupan (the purpose in life). Ada dua bentuk penghayatan hidup yaitu penghayatan hidup bermakna dan penghayatan hidup tidak bermakna. Kedua responden memiliki penghayatan hidup bermakna. Keduanya memiliki aspek-aspek makna hidup diantaranya maksud dan tujuan hidup, kepuasan hidup, kebebasan dan sikap terhadap kematian, sumber-sumber makna hidup diantaranya nilai-nilai kreatif, nilai-nilai penghayatan, nilai-nilai bersikap dan nilai-nilai pengharapan dan juga karakteristik makna hidup dalam kehidupan mereka diantaranya bersifat pribadi, unik dan temporer, bersifat spesifik dan nyata serta memberi pedoman dan arah. Hal tersebut sesuai dengan yang diungkapkan Frankl (dalam Bastaman, 2007).

Kedua responden memiliki penghayatan hidup bermakna karena telah memiliki komponen-komponen pengembangan hidup bermakna yang sesuai dengan apa yang disebutkan oleh Bastaman (2007), yaitu komponenkomponen yang menentukan berhasilnya seseorang dalam merubah hidup dari penghayatan hidup tidak bermakna menjadi lebih bermakna.

Komponen-komponen tersebut adalah pemahaman diri (self insight),
Makna hidup (meaning of life), Pengubahan sikap (changing attitude, Keikatan diri (self commitment), Kegiatan terarah (directed activities), Dukungan sosial (social support) dan ibadah.

Pemahaman diri (self insight) yaitu meningkatkan kesadaran atas buruknya kondisi diri pada saat ini dan keinginan kuat untuk melakukan perubahan ke arah kondisi yang lebih baik. Dalam hal ini keduanya meyakini bahwa status yang mereka miliki adalah bagian dari kehidupan yang harus mereka jalani. Mereka tidak ingin terus menerus meratapi dan mengeluh sebab tidak akan merubah keadaan dan tidak akan mendatangkan manfaat bagi mereka.

Makna hidup (meaning of life), yaitu nilai-nilai penting dan sangat berarti bagi kehidupan pribadi seseorang yang berfungsi sebagai tujuan hidup yang harus dipenuhi. Membahagiakan orang tua yang kini tinggal ibu bagi responden I dan untuk menjadi lebih baik dan selalu merawat rumah peninggalan kedua orangtuanya bagi responden II menjadi tujuan hidup yang harus dipenuhi dan memberi makna bagi mereka setiap hari.

Pengubahan sikap (changing attitude), yaitu Sikap yang semula tidak tepat menjadi tepat dalam menghadapi masalah, kondisi hidup dan musibah yang tidak terekkan. Keduanya tidak ingin terus menerus terpuruk hanya karena status yang mereka miliki sehingga mereka menghadapinya dengan melakukan kegiatan berkarya.

Keikatan diri (self commitment) terhadap makna hidup yang ditemukan dan tujuan hidup yang ditetapkan. Kedua responden berkomitmen untuk mewujudkan keinginan mereka dan 
setiap hari selalu melakukan rutinitas yang sama.

Kegiatan terarah (directed activities), yakni upaya-upaya yang dilakukan secara sadar dan sengaja berupa pengembangan potensi-potensi pribadi, bakat, kemampuan, keterampilan yang positif serta pemanfaatan relasi antar pribadi untuk menunjang tercapainya makna dan tujuan hidup. Keduanya mulai untuk melakukan ibadah dan bekerja sebagai PNS.

Dukungan sosial (social support), yaitu hadirnya seseorang atau sejumlah orang yang akrab, dapat dipercaya, dan selalu bersedia memberi bantuan pada saat-saat diperlukan. Dalam hal ini keduanya selalu mendapat dukungan dari keluarga dan teman terdekat.

Ibadah, yaitu mengembangkan hidup yang bermakna perlu menyertakan bimbingan Tuhan melalui ibadah kepadaNya agar lebih terarah pada tujuan yang baik, tahan menghadapi berbagai hambatan. Do'a dan dzikir adalah inti ibadah yang sangat diperlukan dalam upaya meraih hdup bermakna. Kedua responden melakukan ibadah dan shalat secara tepat waktu, mengaji, berdzikir dan berdo'a setiap harinya.

\section{SIMPULAN}

Faktor-faktor yang menyebabkan keterlambatan menikah pada kedua responden hampir sama walaupun masing-masing responden mempunyai alasan masing-masing sebagai faktor pencetusnya. Responden pertama terlambat menikah disebabkan karena faktor study oriented, punya faktor 'apa- apa' dulu, faktor berbakti kepada orang tua, faktor nikah itu susah dan faktor selera tinggi sedangkan responden kedua terlambat menikah disebabkan karena faktor selera tinggi, faktor berbakti kepada orang tua dan faktor punya 'apaapa' dulu.

Dampak psikologis yang diterima kedua responden berupa memperoleh nilai kebebasan, kemandirian dalam pengambilan keputusan dan dampak negatif berupa kesulitan dalam memenuhi kebutuan seksual sebagai dampak biologis, kesulitan ketika dalam keadaan sakit dan adanya norma yang berasal dari agama dan budaya setempat yang membuat mereka merasa bahwa hidup mereka tidak sempurna karena belum menikah. Strategi coping yang digunakan responden hampir sama. Kedua responden menggunakan strategi coping bentuk problem-focused coping yaitu konfrontasi dan mencari dukungan sosial namun responden kedua juga menggunakan jenis coping merencanakan pemecahan masalah menjadi salah satu yang ia gunakan. Mereka juga menggunakan bentuk emotion-focused coping yaitu penilaian kembali secara positif dan lari/penghindaran namun responden pertama juga menggunakan jenis coping membuat jarak dan kontrol diri. Kedua reponden sangat sensitif jika ada yang menyinggung masalah pernikahan terutama keluarga. Kedua responden menikmati kesibukannya ketika bekerja dan melakukann kegiatan lain sebagai upaya mereka untuk sejenak meupakan permasalahan yang tengah dihadapi. Selain itu keduanya juga menjadikan orang yang dapat mereka percaya 
sebagai tempat berbagi cerita dan berkeluh kesah.

Kedua responden sama-sama memiliki penghayatan hidup bermakna dengan terpenuhinya komponenkomponen pengembangan hidup bermakna. Aspek-aspek makna hidup yang terdiri dari maksud dan tujuan hidup serta sikap responden terhadap kematian berbeda-beda, namun sama dalam aspek-aspek makna hidup yang terdiri dari kepuasan hidup dan kebebasan. Keduanya merasa kepuasan hidup ketika diangkat sebagai PNS dan kebebasan yang digunakan secara wajar dengan batas-batas yang dibuat sendiri oleh masing-masing responden. Kedua responden menerima keadaan dan statusnya saat ini sebagai hal yang terbaik dari Allah dengan tetap bersyukur dan berusaha untuk menjalaninya dengan mengubah pandangan kedua responden menjadi pandangan untuk mampu melihat makna dari penderitaan tersebut. Nilai-nilai pengharapan yang merupakan sumbersumber makna hidup bagi kedua responden salah satunya adalah harapan untuk menikah. Kedua responden samasama memiliki karakteristik makna hidup, kegiatan yang dilakukan kedua responden menantang dan mengundang mereka untuk memenuhinya.

\section{DAFTAR PUSTAKA}

Alcaff, M., \& Qodir, A. (2004). Taman Cinta Surgawi. Jakarta: Pustaka Zahra

Al'Uwaid, R.M. (2005). Telat Menikah Tapi Bahagia. Jakarta Timur: Al'Itishom Cahaya Umat

Atkinson, R. L. \& Ernest. (1999). Pengantar Psikologi. Edisi Kedelapan. Jilid Kedua. Jakarta: Erlangga
Burhan. (2003). Analisis Data Kualitatif. Jakarta: PT Raja Grafindo Persada

Bastaman, D.H. (2005). Logoterapi: Psikologi Untuk Menemukan Makna Hidup dan Meraih Hidup Bermakna. Jakarta: PT Raja Grafindo Persada

Chaplin, J.P. (200o). Kamus Lengkap Psikologi. Penerjemah: Kartini Kartono. Jakarta: CV Rajawali

Dariyo, A. (2008). Psikologi Perkembangan Dewasa Muda. Jakarta: PT Gramedia Widisarana Indonesia

Feinberg, R.M. (2005). Mengenali Tanda-tanda Kedewasaan Pada Diri Seseorang. http://warmada.staff.ugm.ac.id/Life/kema tangan.html. Akses 29 November 2017, Jam 21.10 WIB

Hurlock, E.B. (1980). Psikologi Perkembangan. Edisi Kelima. Jakarta: Erlangga

Koeswara, E. (1992). Logoterapi: Psikoterapi Victor Frankl. Yogyakarta: Kanisius

Moleong, J.L. (2005). Metodologi Penelitian Kualitatif. Edisi Revisi. Bandung: PT Remaja Rosda Karya

Monks, F.J. Knoers A.M.P. \& Rahayu, H.S. (2004). Psikologi Perkembangan Pengantar Dalam Berbagai Bagiannya. Edisi Kelima Belas. Yogyakarta: Gajah Mada University Press

Muhyiddin, H.A. (2004). Dilema Wanita Terlambat Menikah. Jakarta Timur: Pustaka Al-Kautsar

Papalia, W.E. Olds, S.W. \& Feldman, R.D. (2008). Human Development (Psikologi Perkembangan). Jakarta: Kencana

Poerwandari, E.K. (2007). Pendekatan Kualitatif Untuk Penelitian Perilaku Manusia. Jakarta: Lembaga Pengembangan Sarana Pengukuran dan Pendidikan Psikologi Faklutas Psikologi Universitas Indonesia

Santrock, J.W. (1995). Life Span Development. Edisi Kelima. Jilid Kedua. Jakarta: Erlangga

Smeth, B. (1994). Psikologi Kesehatan. Semarang: Grasindo

Stewart, C.J. \& Cash, W.B. (200o). Interviewing Principles and Practices. Boston: McGraw_Hill Companies

Subyantoro, A. \& Suwarto F.X. (2006). Metode dan Teknik Penelitian Sosial. Yogyakarta: Andi Yogyakarta

Thariq, A.K. (2005). Psikologi Suami Istri. Yogyakarta: Mitra Pustaka 